\title{
What Entrepreneurs Can Learn From Kiwi Crisis Management
}

\author{
Jamie Collins (University of Canterbury)
}

KEYWORDS: Management, Strategy, crisis management.

Entrepreneurs often face critical decisions for their firms in the midst of considerable uncertainty and great risk. Effective crisis management requires that decision makers make choices even when they have imperfect information and poorly defined options. Leaders must balance the well-being of their businesses and their employees while maintaining critical stakeholder relationships beyond the crisis. The wrong decision can have dire consequences.

Business owners can glean insights from how New Zealanders (also known as Kiwis) dealt with the COVID-19 crisis. New Zealand's strategies allowed it to escape the worst of the pandemic.

Globally, it's still a perilous and uncertain time for decision makers at entrepreneurial firms. Rates of unemployment not seen since the Great Depression have created extreme uncertainty for most small firms. Widely varied government-ordered quarantines and shutdowns disrupt the potential to continue business operations across multiple markets. Poorly equipped health systems, economic disruption, institutional inertia, bureaucracy, societal discord and political obstacles each present challenges to developing a longterm solution to the risks posed by COVID- 19 .

However, entrepreneurs around the globe can face their own crises with clarity by adopting these practices illustrated by the New Zealand example:

- Rely on available relevant data to drive decisions.

- Frequently communicate with key constituents.

- Be as transparent as possible when making decisions.

- Above all else, acknowledge the human impact of decisions.

\section{New Zealand's Success Against}

\section{COVID-19}

New Zealand has experienced notable success in combating COVID-19. In order to manage risks associated with the disease, the country enacted very tough restrictions before any reported deaths from the disease. Borders were closed to international visitors; domestic travel was severely limited; all schools and public activities were closed; a mandatory lockdown prohibited all but essential activities. Most economic activity and all social activities were severely disrupted for nearly two months as part of New Zealand's proactive approach to combating the disease. While hundreds of thousands of people around the world have died from COVID-19, to date New Zealand has had among the lowest per capita rates of infection of any highly developed Western nation, and fewer than two dozen deaths from the disease.

New Zealand's geographic isolation from the rest of the world surely has helped, but a significant portion of the country's relative success has been because of its leadership. Jacinda Ardern, New Zealand's Prime Minister, spearheaded a government-wide effort to steer the country through the uncharted risks of the pandemic. Her leadership is an excellent example of using personal authority to lead during crisis. Unlike other world leaders, she did not default to relying on the authority vested in her government position to inspire compliance. Instead, Ardern leaned on the public's trust in her, based on her personal authority, to lead in the midst of the crisis.

\section{Rely on data to drive decisions.}

Kiwis rallied to take a science-driven approach to dealing with the risks posed by the disease. For example, a COVID-19 alert system was created to provide detailed information regarding risks and steps to manage those risks at each level of alert. In addition to promoting guidelines published by the World Health 
Organization, New Zealand widely shared epidemiologists' recommendations for ways to minimize the risk of spreading the virus. Similarly, entrepreneurs should use the best available, relevant data when navigating their firms through an emergency. A datadriven decision making process improves the quality of decisions. Minimizing the perceived arbitrariness of key decisions also gives your constituents (employees, customers, suppliers, partners, etc.) more confidence in your judgment.

\section{Frequently communicate with key constituents.}

A public information campaign was launched to keep New Zealanders updated on the evolving situation in terms of the government's continuing response. Daily press briefings highlighted public health updates as well as societal, economic and political implications of key government decisions. These daily briefings were supplemented by online information from the Ministry of Health that was also shared via media outlets. Maintaining ongoing communication with important constituents is vital for entrepreneurial leaders as they chart a path forward during an existential crisis. Doing so improves constituents' understanding of constraints, options and choices.

\section{Be as transparent as possible when making decisions.}

Significant data regarding rates of infection, sources of infection, location of cases and specific data pertaining to individual cases were shared with New Zealanders to build confidence in decisions. On the strength of building a data-driven case for recommended actions, Kiwis were asked to work together to achieve the collective goal of eliminating the disease in the country. Ardern repeatedly asked New Zealanders to work as a "team of five million" to combat the disease. When entrepreneurial leaders are as transparent as possible, critical stakeholders see that they are credible. People generally understand that crises are accompanied by several potential poor outcomes and major disruptions; they also value transparency from leadership about the nature of this reality.

\section{Above all else, acknowledge the human impact of decisions.}

The restrictions adopted had a direct impact on the lives of all 5 million people living in New Zealand. The decision to enter complete lockdown caused significant financial harm to many New Zealanders, cost thousands of Kiwis their jobs, and disrupted the existing social order throughout the country. Ardern repeatedly assured Kiwis that she understood the sacrifices they were being asked to make. She also went to great pains to use personal examples (her own and others') to highlight the human impact of such decisions. Ardern has received wide praise for her leadership throughout the government's response to COVID-19. In fact, she has been labeled as one of the world's best leaders by top global media outlets. She has exhibited enviable key strengths through the COVID crisis as well as after a prior horrific terrorist attack in New Zealand. Her accessibility to constituents, her ability to articulate a clear well-reasoned vision in the midst of chaos and uncertainty, and her relentless focus on the human impact of difficult choices have been exemplars of how to lead during a crisis.

Entrepreneurs often face crises that may determine whether their organizations survive. Organizational survival through such times likely requires painful choices that have a very real impact on the lives of stakeholders. Closure of facilities, furloughs, cancellation of existing plans, compensation changes, changes in operating routines/schedules, and modifications to how the firm interacts with its customers (among others) all have the potential to negatively impact how people live their lives. The odds of survival for entrepreneurial firms vastly improve if they rely on a decision-making process that recognizes the human impact of decisions. 